\title{
OPTIMALISASI KELAS IBU HAMIL SEBAGAI UPAYA PENINGKATAN KESEHATAN MASA KEHAMILAN
}

\author{
Siti Rofi'aha*) ; Sri Widatiningsih ${ }^{\mathrm{b}}$; Siti Chunaenic $^{\mathrm{c}}$ \\ $a, b, c$ Jurusan Kebidanan; Poltekkes Kemenkes Semarang \\ Jl. Tirto Agung ; Pedalangan ; Banyumanik ; Semarang
}

\begin{abstract}
Abstrak
Emesis gravidarum dapat menyebabkan stress bagi ibu hamil sehingga dapat mempengaruhi kehamilan dan gangguan perkembangan janin. Salah satu cara agar ibu hamil mampu mengatasi keluhannya secara lebih aman adalah memberikan informasi tentang terapi non farmakologis dengan optimalisasi kelas ibu hamil melalui peran kader kesehatan. Tujuan pengabdian masyarakat ini adalah untuk meningkatkan pengetahuan dan perilaku ibu hamil dalam mengatasi emesis gravidarum menggunakan terapi non farmakologis dengan optimalisasi kelas ibu hamil melalui peran kader kesehatan. Metode yang dilaksanakan dengan ceramah, diskusi, demonstrasi, tanya jawab dan praktik. Kegiatan ini mampu meningkatkan rata-rata pengetahuan sebesar 8,1 dan $21(57 \%)$ kader memiliki ketrampilan baik. Optimalisasi kelas ibu hamil sangat tepat dalam meningkatkan tingkat pengetahuan dan ketrampilan kader sehingga mereka mampu mendampingi ibu hamil sebagai upaya peningkatan kesehatan masa kehamilan dalam mengatasi emesis gravidarum menggunakan terapi non farmakologis. Diharapkan Bidan Desa maupun Puskesmas yang terlibat aktif dalam kesehatan masa kehamilan agar terus membina serta memantau kegiatan dalam upaya meningkatkan kesehatan masa kehamilan.
\end{abstract}

Kata kunci: kelas ibu hamil; kesehatan masa kehamilan

\begin{abstract}
[Optimization Of Pregnant Mom Class As An Effort To Improve Pregnancy Of Pregnancy] Emesis gravidarum can cause stress for pregnant women so that it can affect pregnancy and fetal development disorders. One way for pregnant women can be able to handle their complaints more safely is to provide information about non-pharmacological therapy by optimizing the class of pregnant women through the role of health cadres. The aim of community service is increasing the knowledge and behavior of pregnant women in overcoming emesis gravidarum using non-pharmacological therapy by optimizing the class of pregnant women through the role of health cadres. The method was carried out with lectures, discussions, demonstrations, question and answer and practice. This activity was able to increase the average of 8.1 and 21 (57\%) cadres had good skills. Optimizing the class of pregnant women was very appropriate in increasing the level of knowledge and skills of cadres so that they are able to assist pregnant women as an effort to improve pregnancy health in overcoming emesis gravidarum using non-pharmacological therapy. It is expected that both the village midwives and public health centers who are actively involved in the health of pregnancy can continue to foster and monitor activities in an effort to improve the health of the pregnancy.
\end{abstract}

Keywords: the class of pregnant, the health of the pregnancy

\section{Pendahuluan}

Kehamilan merupakan suatu proses yang berkesinambungan dimulai dari ovulasi pelepasan sel telur, migrasi spermatozoa dan ovum, konsepsi dan pertumbuhan zigot, nidasi

*) Penulis Korespondensi (Siti Rofi'ah)

E-mail: nandasheeta@yahoo.com (implantasi) pada uterus, pembentukan plasenta, dan tumbuh kembang hasil konsepsi sampai aterm (Manuaba, Manuaba and Manuaba, 2010). Mual atau nausea dan muntah atau yang biasa disebut emesis gravidarum merupakan gejala yang umum dan sering terjadi pada kehamilan trimester awal. Mual 
biasanya muncul pada pagi hari (morning sickness), namun dapat pula timbul setiap saat dan malam hari. Gejala-gejala ini kurang lebih terjadi setelah enam minggu dari hari pertama haid terakhir dan berlangsung selama kurang lebih 10 minggu. Mual dan muntah terjadi pada $60-80 \%$ primigravida dan $40-60 \%$ terjadi pada multigravida. Satu diantara seribu kehamilan gejala-gejala lain menjadi berat (Saifuddin, 2011). Mual muntah yang terjadi pada kehamilan disebabkan karena peningkatan kadar hormon estrogen dan progesteron yang diproduksi oleh Human Chorionic Gonadotropine (HCG) dalam serum dari plasenta (Aritonang, 2010).

Derajat keluhan mual muntah yang dirasakan oleh setiap ibu hamil tidak sama. Hasil penelitian (Madjunkova, Maltepe and Koren, 2013) menyebutkan bahwa $95 \%$ ibu hamil mengalami mual muntah dari tingkat sedang hingga berat., $13 \%$ berkembang menjadi hiperemesis gravidarum. Mual muntah baik derajat ringan, sedang maupun parah dapat menimbulkan dampak negatif pada kehamilan, dampak terhadap keluarga, kerja, dan kehidupan sosial. Dampak kualitas hidup selain berupa fisik juga emosi. Wanita sering menyampaikan perasaan terisolasi, lemah, depresi, kegelisahan, frustasi, sulit mengatasi, serta cepat marah. Wanita juga mengeluhkan aktivitas yang biasa dilakukan menjadi terganggu (Mattison, 2013). Emesis gravidarum dengan kasus berat dapat menyebabkan efek negatif pada janin, seperti berat badan lahir rendah dan prematuritas (MV et al., 2011).

Pada umumnya wanita hamil mampu menyesuaikan dengan keadaan mual muntah yang dialami meskipun hingga berbulan-bulan. Keluhan ini merupakan hal yang fisiologis, namun jika tidak segera diatasi dapat menjadi hal yang patologis (Saifuddin, 2011). Gejala emesis gravidarum selain diatasi menggunakan terapi farmakologis juga dapat ditangani dengan menggunakan non farmakologis. Terapi non farmakologis dapat digunakan sebagai alternatif untuk mengurangi keluhan mual muntah pada ibu hamil karena aman dan dapat meminimalkan efek samping baik bagi ibu maupun janin. Terapi non farmakologis dalam mengatasi emesis gravidarum antara lain dengan pemberian aromaterapi lemon (Rofi'ah, Widatiningsih and Sukini, 2019), minuman kombinasi jahe sereh (Rofi'ah, Handayani and Rahmawati, 2017), kumur dengan rempah cengkeh (Widatiningsih, Rofiah and
Ristiyanawati, 2018), pemberian permen jahe (Nurdiana, 2018).

Hasil penelitian dengan judul Studi Fenomenologi Kejadian Hiperemesis Gravidarum menyebutkan bahwa dari delapan orang informan yang dilakukan wawancara mendalam hanya satu orang yang menggunakan terapi non farmakologis dalam mengatasi keluhannya. Jawaban informan menyatakan bahwa keluhan mual muntahnya tersebut hanya diatasi menggunakan obat-obatan yang diberikan oleh tenaga kesehatan, hal tersebut menyebabkan ketergantungan pada tenaga kesehatan dan terapi farmakologis yang diterima (Rofi'ah, Widatiningsih and Arfiana, 2019). Oleh karena itu, seorang ibu hamil diharapkan memiliki pengetahuan yang cukup mengenai mual muntah pada kehamilan sehingga dapat menentukan sikap dan perilaku untuk mengatasi masalahnya. Hal ini sesuai penelitian (Sulate, 2015) bahwa ada hubungan pengetahuan ibu hamil ibu hamil tentang emesis gravidarum dengan perilaku ibu hamil pada saat mengalami emesis gravidarum.

Salah satu program pemerintah dalam upaya meningkatkan pengetahuan ibu hamil agar mampu mengenali dan mengatasi keluhan saat kehamilannya adalah dengan Program Kelas Ibu Hamil. Kelas ibu hamil merupakan sarana untuk belajar bersama tentang kesehatan bagi ibu hamil, dalam bentuk tatap muka dalam kelompok yang bertujuan untuk meningkatkan pengetahuan dan keterampilan ibu-ibu mengenai kehamilan, persalinan, nifas, KB pasca persalinan, pencegahan komplikasi, perawatan bayi baru lahir dan aktivitas fisik atau senam ibu hamil. Tujuan kelas ibu hamil adalah meningkatkan pengetahuan, merubah sikap dan perilaku ibu agar memahami tentang pemeriksaan kehamilan agar ibu dan janin sehat, persalinan aman, nifas nyaman ibu selamat, bayi sehat, pencegahan penyakit fisik dan jiwa, gangguan gizi dan komplikasi kehamilan, persalinan dan nifas agar ibu dan bayi sehat, perawatan bayi baru lahir agar tumbuh kembang optimal serta aktivitas fisik ibu hamil (Kemenkes RI, 2014).

Pelaksanaan kelas ibu hamil tidak terlepas dari peran kader kesehatan untuk mendampingi ibu hamil dalam melakukan perubahan perilaku sebagai upaya menekan angka kematian ibu dan bayi. Kader posyandu dapat bertindak sebagai agen perubahan yang bertugas menumbuhkan kesadaran ibu hamil 
akan pentingnya perilaku sehat selama masa kehamilan. Peranan kader posyandu meliputi melakukan kegiatan pendataan (arsip), bertindak sebagai komunikator kesehatan, melakukan pendekatan dan persuasif, melakukan visitasi, menjadi penghubung dan mengadakan pengawasan dan evaluasi (Susanto, 2017). Optimalisasi kelas ibu hamil sebagai upaya peningkatan kesehatan masa kehamilan dengan memberdayakan kader kesehatan untuk melakukan transfer of knowledge serta pendampingan cara mengatasi mual muntah menggunakan terapi non farmakologis.

Desa Kalijoso Kecamatan Secang Kabupaten Magelang adalah salah satu desa yang cukup maju dan mudah dalam menerima pembaharuan. Kelas ibu hamil sudah berjalan baik, namun berdasarkan wawancara dengan bidan desa pada tanggal 6 Februari 2018 diperoleh hasil bahwa hingga saat ini ibu hamil meskipun sudah menerima informasi saat kelas ibu hamil tentang keluhan mual muntah saat kehamilan terutama pada trimester I namun mereka masih mengandalkan bidan dalam penanganannya. Ibu hamil cenderung menggunakan terapi non farmakologis. Mereka belum menggunakan terapi non farmakologis dalam mengatasi keluhan yang dirasakan.

Berdasarkan hal tersebut maka civitas akademika Poltekkes Kemenkes Semarang Prodi D III Kebidanan Magelang mengadakan kegiatan pengabdian masyarakat berupa penerapan hasil penelitian dosen tentang Optimalisasi Kelas Ibu Hamil sebagai Upaya Peningkatan Kesehatan Masa Kehamilan dalam Mengatasi Emesis Gravidarum Menggunakan Terapi Non Farmakologis

\section{Metode}

Metode yang dilakukan dalam kegiatan pengabdian masyarakat ini yaitu dengan langkah sebagai berikut :

a. Koordinasi dengan Bidan Desa untuk melakukan kegiatan pengabdian masyarakat

b. Mengajukan permohonan ijin ke Puskesmas Secang dan Kepala Desa Kalijoso.

c. Melakukan pertemuan dengan kader dan bidan desa untuk menjelaskan tentang pelaksanaan kegiatan pengabdian masyarakat berupa Optimalisasi Kelas Ibu Hamil sebagai Upaya Peningkatan Kesehatan Masa Kehamilan dalam Mengatasi Emesis Gravidarum Menggunakan Terapi Non Farmakologis d. Melakukan kegiatan pengabdian masyarakat dengan materi : Pengenalan tentang mual muntah dan Cara Mengatasinya, Cara mengatasi mual muntah dengan Dukungan Psikologis dan Intervensi Fisik serta cara mengatasi mual muntah dengan intervensi konsumsi makanan / minuman. Kegiatan dilaksanakan selama 5 kali pertemuan dengan metode ceramah, diskusi, demonstrasi, tanya jawab dan praktik.

e. Kegiatan diawali dengan pre test pada saat pertemuan pertama dan post test pada pertemuan ke lima ceramah, diskusi, meliputi pengetahuan dan ketrampilan pendampingan.

Sasaran kegiatan ini yaitu ibu-ibu kader posyandu Desa Kalijoso Kecamatan Secang sebanyak 37 orang. Kegiatan pengabdian masyarakat ini melibatkan Bidan Desa, mahasiswa Poltekkes Kemenkes Semarang Prodi D III Kebidanan Magelang sebanyak 5 (lima orang) dan Dosen Poltekkes Kemenkes Semarang Prodi Kebidanan Magelang sebanyak 3 (tiga) orang. Sarana dan alat yang digunakan dalam kegiatan ini meliputi ruangan yang nyaman, LCD, Laptop, serta modul.

\section{Hasil dan Pembahasan}

Kegiatan Pengabdian Masyarakat “Optimalisasi Kelas Ibu Hamil sebagai Upaya Peningkatan Kesehatan Masa Kehamilan dalam Mengatasi Emesis Gravidarum Menggunakan Terapi Non Farmakologis" telah berhasil meningkatkan pengetahuan dan ketrampilan kader melakukan pendampingan kepada ibu hamil dalam mengatasi emesis gravidarum. Hal tersebut dapat dilihat dari pre test dan post test yang dilaksanakan sebelum dan setelah kegiatan selesai dilakukan. Penilaian terhadap pengetahuan menggunakan kuesioner tertutup, sedangkan tindakan dengan mengisi checklist yang telah disediakan.

Tabel 1. Perubahan Tingkat Pengetahuan Sebelum dan Sesudah Kegiatan Pengabdian Masyarakat

\begin{tabular}{lcc}
\hline \multicolumn{1}{c}{$\begin{array}{c}\text { Tingkat } \\
\text { Pengetahuan }\end{array}$} & Sebelum & Sesudah \\
\hline Mean & 85.41 & 93.51 \\
Minimum & 40 & 40 \\
Maximum & 100 & 100 \\
\hline
\end{tabular}


Tabel 2. Hasil Analisa Statistik Kegiatan Pengabdian Masyarakat Optimalisasi Kelas Ibu Hamil

\begin{tabular}{lc}
\hline Tingkat Pengetahuan & Hasil Analisa \\
\hline Naik & 20 \\
Turun & 1 \\
Tetap & 16 \\
p-value & 0.0001 \\
Nilai Z & -3.891 \\
\hline
\end{tabular}

Hasil pre test tingkat pengetahuan diperoleh hasil rata-rata sebesar 85,41 sedangkan post test sebesar 93,51. Dari 37 orang kader yang mengalami kenaikan skor pengetahuan sebanyak 20 orang, yang tetap 16 orang. Hasil analisa statistik diperoleh $\mathrm{p}$ value 0,0001 dengan nilai $\mathrm{z} \quad-3.981$ Hal ini menunjukkan bahwa ada perbedaan tingkat pengetahuan sebelum dan sesudah kegiatan pendampingan sebesar 4 kali lipat. Kegiatan optimalisasi kader dalam kelas ibu hamil cukup efektif meningkatkan tingkat pengetahuan kader tentang penggunaan terapi non farmakologis dalam mengatasi emesis gravidarum sebagai upaya peningkatan kesehatan masa kehamilan. Hal ini sesuai dengan kegiatan pengabdian masyarakat yang dilaksanakan oleh (Setyaningsih, Adriyani and Ulfah, 2016) dengan hasil kegiatan pelatihan kader mampu meningkatkan rerata skor pengetahuan ibu hamil tentang kehamilan dan tanda bahaya dalam kehamilan dalam rentang rentang 14 sampai 16 point.

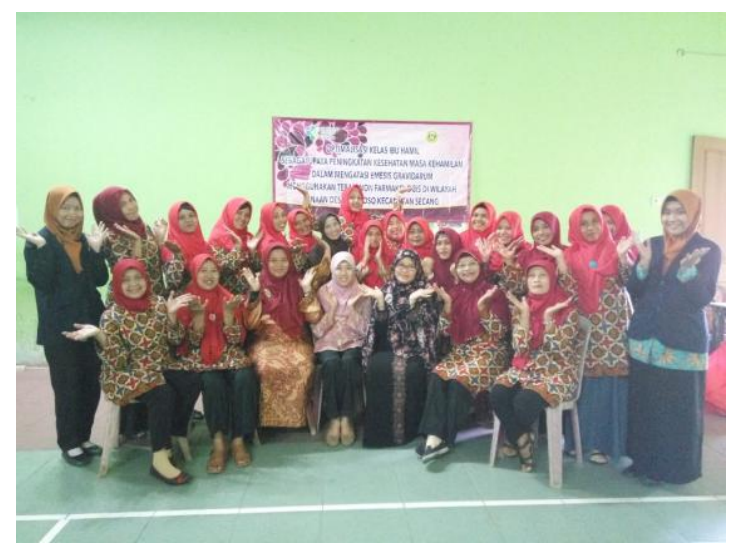

Gambar 1. Peserta Kegiatan pengabdian masyarakat bersama Tim Pengabdi Poltekkes

Kemenkes Semarang Prodi Kebidanan Magelang

Kegiatan pengabdian masyarakat berupa “Optimalisasi Kelas Ibu Hamil sebagai Upaya Peningkatan Kesehatan Masa Kehamilan dalam
Mengatasi Emesis Gravidarum Menggunakan Terapi Non Farmakologis" telah dilaksanakan sebanyak 5 kali pertemuan. Pada saat pertemuan pertama dilakukan penjelasan awal kegiatan pengabdian masyarakat "Optimalisasi Kelas Ibu Hamil sebagai Upaya Peningkatan Kesehatan Masa Kehamilan dalam Mengatasi Emesis Gravidarum Menggunakan Terapi Non Farmakologis"yang dihadiri oleh 37 orang kader. Pada pertemuan ini dijelaskan bentuk kegiatan pengabdian masyarakat yaitu melatih kader agar mampu mendampingi ibu hamil untuk mengatasi mual muntah menggunakan terapi non farmakologis sehingga dapat menekan efek samping.

Pada pemantauan ketrampilan melakukan pendampingan pada ibu hamil yang mengalami emesis gravidarum diperoleh hasil 21 orang kader memiliki ketrampilan yang baik saat melakukan transfer of knowledge pada ibu hamil yang mengalami emesis gravidarum. Sebagai tindak lanjut perlu latihan untuk melakukan pendampingan terutama pada 16 orang kader yang memiliki ketrampilan masih kurang dalam melakukan pendampingan bagi ibu hamil yang mengalami keluhan mual muntah.

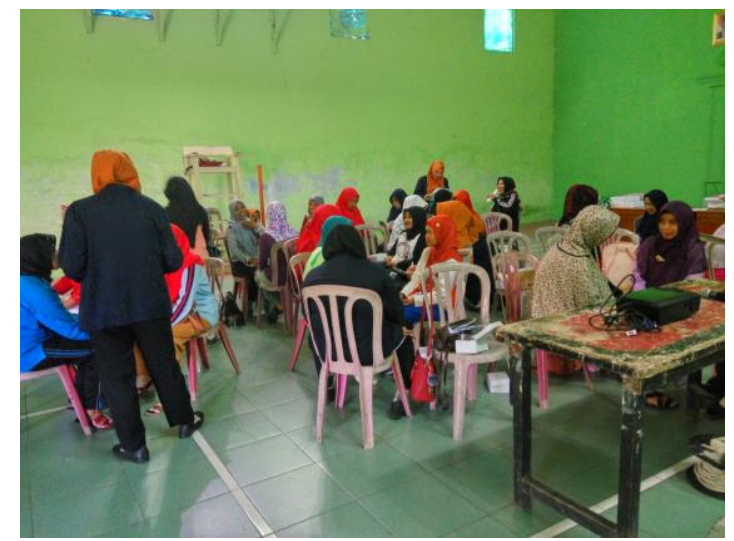

Gambar 2. Simulasi Kegiatan Pendampingan Ibu hamil yang mengalami mual muntah

Kader merupakan penggerak masyarakat untuk sadar akan kesehatan ibu dan anak. Kader kesehatan sebagai perpanjangan tangan bidan akan sangat baik dalam mendampingi masyarakat untuk menciptakan keluarga sehat. Hal ini sesuai hasil penelitian (Wijhati, Suryantoro and Rokhanawati, 2017) yang menyatakan bahwa ada hubungan yang signifikan antara peran kader dengan pemanfaatan buku KIA. Kader yang berperan baik meningkatkan kemungkinan ibu untuk memanfaatkan buku KIA sebagai sumber informasi dalam perawatan anak. Kader yang 
memiliki tingkat pengetahuan yang baik serta aktif dalam kegiatan di masyarakat akan sangat membantu masyarakat dalam merubah perilaku yang positif dalam bidang kesehatan. Peningkatan pengetahuan ibu hamil dan kader diharapkan akan berbanding lurus dengan perubahan perilaku ibu hamil serta peningkatan partisipasi kader dalam pendampingan ibu hamil yang pada akhirnya dapat menurunkan angka kematian ibu. Demikian halnya dengan perilaku ibu hamil menggunakan terapi non farmakologis dalam mengatasi emesis gravidarum.

Peran serta kader dalam mendampingi ibu hamil untuk mengatasi keluhan emesis gravidarum menggunakan terapi non farmakologis dalam upaya peningkatan kesehatan masa kehamilan dengan cara mengoptimalkan kelas ibu hamil. Hal ini sesuai penelitian (Muhith et al., 2019) yang menyatakan bahwa ada pengaruh kelas ibu hamil terhadap pengetahuan kader dalam deteksi dini resiko ibu hamil. Kegiatan Kelas Ibu Hamil adalah bentuk intervensi pada tahap awal siklus hidup manusia. Kegiatan ini sangat membantu ibu hamil dalam pengetahuan, sikap dan perilaku pencegahan risiko dan komplikasi kehamilan oleh ibu hamil menjadi lebih baik. Ibu hamil menjadi lebih intensif melakukan kunjungan ANC setiap bulan ke Bidan Desa setempat (Fibriana and Azinar, 2016). Salah satu pengetahuan, sikap dan perilaku yang dipelajari saat kelas ibu hamil adalah keluhan umum saat kehamilan, salah satunya mual muntah.

Mual muntah merupakan keluhan ibu hamil yang biasa terjadi pada trimester awal kehamilan. Biasanya mual muntah muncul setelah ibu dinyatakan hamil berdasarkan hasil pemeriksaan PP test. Munculnya keluhan ini akibat sikap ibu hamil terhadap keadaan kehamilannya. Untuk mengatasi keadaannya tersebut biasanya ibu hamil akan segera mendatangi petugas kesehatan baik bidan, dokter atau ke fasilitas pelayanan kesehatan (Rofi'ah, Widatiningsih and Arfiana, 2019). Keluhan mual muntah seperti pada penelitian (Widiasari and Trapika, 2017) cenderung pemberian diberikan farmakoterapi dibandingkan dengan non-farmakoterapi secara umum. Banyak penelitian yang menunjukkan bahwa mual muntah pada kehamilan dapat diatasi dengan menggunakan non farmakoterapi baik berupa makanan atau minuman maupun intervensi lain. Beberapa non farmakoterapi untuk mengurangi keluhan mual muntah pada ibu hamil antara lain minuman jahe hangat (Wulandari, Kustriyanti and Aisyah, 2019), Pemberian sirup jahe merah (Suparmi and Kusumadewi, 2018), pemberian terapi aroma jeruk (Dhilon and Azni, 2018), pemberian aromaterapi ginger oil (Carolin and Ummah, 2019); konsumsi es krim (Kiswati, 2017), pemberian self management module morning sickness (Latifah, Setiawati and Dwi, 2017), dan pemberian akupresure titik p6 (Mariza and Ayuningtias, 2019).

Beberapa hasil penelitian tersebut yang mendasari kegiatan pengabdian masyarakat untuk memberikan pemahaman dan ketrampilan kepada kader tentang terapi non farmakologis dalam mengatasi keluhan mual muntah. Kegiatan pengabdian masyarakat berupa penerapan Hasil Penelitian : “Optimalisasi Kelas Ibu Hamil sebagai Upaya Peningkatan Kesehatan Masa Kehamilan dalam Mengatasi Emesis Gravidarum Menggunakan Terapi Non Farmakologis" ditindak lanjuti dengan pemantauan kegiatan kader dalam melakukan pendampingan kepada ibu hamil yang mengalami emesis gravidarum melalui kegiatan rutin evaluasi desa binaan. Kegiatan tersebut dilaksanakan baik melalui kegiatan PKL PKMD maupun eveluasi rutin bulanan dengan bekerjasama dengan bidan Desa Kalijosos Kecamatan Secang Kabupaten Magelang.

\section{Simpulan dan Saran}

Kegiatan pengabdian masyarakat berupa “Optimalisasi Kelas Ibu Hamil sebagai Upaya Peningkatan Kesehatan Masa Kehamilan dalam Mengatasi Emesis Gravidarum Menggunakan Terapi Non Farmakologis" mampu meningkatkan tingkat pengetahuan dan ketrampilan kader dalam kelas ibu hamil sebagai upaya peningkatan kesehatan masa kehamilan. Luaran yang dicapai dalam kegiatan pengabdian masyarakat ini adalah tersusunnya modul sebagai media dalam melakukan pendampingan pada ibu hamil yang mengalami emesis gravidarum yang telah bersertifikat hak cipta.

Bidan Desa maupun Puskesmas yang terlibat aktif dalam kesehatan masa kehamilan agar terus membina serta memantau kegiatan pendampingan kader dalam mengatasi emesis gravidarum menggunakan terapi non farmakologis oleh kader posyandu di Desa Kalijoso Kecamatan Secang sehingga dapat 
secara terus menerus dan berkelanjutan untuk mendampingi dan membimbing ibu hamil dalam upaya meningkatkan kesehatan masa kehamilan.

Tim pengabdian masyarakat perlu memberikan pendampingan dan evaluasi berkala terkait kegiatan pendampingan kader dalam mengatasi emesis gravidarum oleh kader posyandu di Desa Kalijoso Kecamatan Secang. Hal ini dapat dilaksanakan dengan melakukan koordinasi dengan bidan desa dan Puskesmas setempat. Selain itu juga diperlukan kegiatan refreshing pengetahuan dan ketrampilan kader secara berkala agar pelaksanaan pendampingan tetap dapat terlaksana secara terus menerus

\section{Ucapan Terima Kasih}

Dalam pelaksanaan kegiatan ini penulis menyampaikan rasa terima kasih yang sebesar-besarnya atas terselenggaranya kegiatan pengabdian masyarakat ini kepada Kepala Puskesmas Secang I, Bidan Koordinator Puskesmas Secang I, Bidan Desa Kalijoso, Pemerintah Desa Kalijoso, Kader Posyandu Desa Kalijoso, Direktur Poltekkes Kemenkes Semarang, Perwakilan Jurusan Kebidanan Magelang, Tim UPPM Poltekkes Kemenkes Semarang, mahasiswa Prodi D III Kebidanan Magelang serta tim pengabdian masyarakat

\section{Daftar Pustaka}

Aritonang, E. (2010) Kebutuhan Gizi Ibu Hamil. Bogor: IPB Press.

Carolin, B. T. and Ummah, A. H. (2019) ‘Pengaruh Pemberian Aromaterapi Ginger Oil ( Zingiber officinale ) Terhadap Emesis Gravidarum Pada Ibu Hamil Trimester I Di Klinik Makmur Jaya Tahun 2019', Jurnal Kesehatan Qamarul Huda, 7(1), pp. 1-5.

Dhilon, D. A. and Azni, R. (2018) 'Pengaruh Pemberian Terapi Aroma Jeruk terhadap Intensitas Rasa Mual dan Muntah pada Ibu Hamil di Wilayah Kerja Puskesmas Harapan Raya', Jurnal Doppler Universitas Pahlawan Tuanku Tambusai, 2(1), pp. 58-65.

Fibriana, A. I. and Azinar, M. (2016) 'Model Kelas Ibu Hamil untuk Pemetaan Risiko Kehamilan dan Pencegahan Komplikasi Persalinan', Jurnal Abdimas, 20(1), pp. 11-18.

Kemenkes RI (2014) Pedoman Pelaksanaan Kelas Ibu Hamil. Cetakan Ta, Kementrian Kesehatan RI. Cetakan Ta. Jakarta: DirektoratJenderal Bina Gizi dan KIA. doi: 351.077 Ind r.
Kiswati, K. (2017) 'The Benefit of Ice Cream to Reduce Emesis Gravidarum of Pregnant Woman', IOSR Journal of Nursing and Health Science, 06(01), pp. 40-45. doi: 10.9790/1959-0601084045.

Latifah, L., Setiawati, N. and Dwi, E. H. (2017) 'Efektifitas Self Management Module dalam Mengatasi Morning Sickness Effectiveness Self Management Module in Overcoming Morning Sickness', Jurnal Keperawatan Fikkes UnSoed, 5(1), pp. 10-18. Available at: https://www.researchgate.net/publication /319249434_Efektifitas_Self_Management_ Module_dalam_Mengatasi_Morning_Sickn ess/link/59a0b54ea6fdcc1a31483ff0/downl oadment-module-dalam.pdf.

Madjunkova, S., Maltepe, C. and Koren, G. (2013) 'The Leading Concerns of American Women with Nausea and Vomiting of Pregnancy Calling Motherisk NVP Helpline', Obstetrics and Gynecology International, 2013, pp. 1-7. doi: $10.1155 / 2013 / 752980$.

Manuaba, I. A. C., Manuaba, I. B. G. F. and Manuaba, I. B. G. (2010) Ilmu Kebidanan, Penyakit Kandungan dan KB untuk Pendidikan Bidan. Edisi Kedu. Jakarta: EGC.

Mariza, A. and Ayuningtias, L. (2019) 'Penerapan Akupresur pada Titik P6 terhadap Emesis Gravidarum pada Ibu Hamil Trimester 1', Holistik Jurnal Kesehatan, 13(3), pp. 218-224.

Mattison, D. R. (2013) Clinical Pharmacology During Pregnancy. Academic Press. Available at: https://www.sciencedirect.com/book/978 0123860071/clinical-pharmacology-duringpregnancy.

Muhith, A. et al. (2019) 'Pelaksanaan Kelas Ibu Hamil sebagai Upaya Peningkatan Pengetahuan Ibu, Keluarga dan Kader dalam Deteksi Dini Resiko Tinggi Ibu Hamil di Wilayah Kerja Puskesmas Sambeng Kabupaten Lamongan', Care : Jurnal Ilmiah Ilmu Kesehatan, 7(1), pp. 37-44. doi: 10.33366/jc.v7i1.1084.

MV, V. et al. (2011) 'Consequence of Hypermesis Gravidarum for Offspring : a Systematic Review and Meta-analysis', International Journal of Obstetrics and Gynaecology, 118(11), pp. 1302-1313. Available at: https://www.ncbi.nlm.nih.gov/pubmed/ 21749625.

Nurdiana, A. (2018) 'Efektifitas Pemberian 
Permen Jahe terhadap Mual Muntah pada Ibu Hamil di Klinik Khairunida Sunggal Tahun 2018', Jurnal iImiah PANNMED, 13(1), pp. 12-16.

Rofi'ah, S., Handayani, E. and Rahmawati, T. (2017) 'Efektivitas Konsumsi Jahe Dan Sereh Dalam Mengatasi Morning Sickness', Jurnal Ilmiah Bidan, 2(2), pp. 57-63.

Rofi'ah, S., Widatiningsih, S. and Arfiana, A. (2019) 'Studi Fenomenologi Kejadian Hiperemesis Gravidarum Pada Ibu Hamil Trimester I', Jurnal Riset Kesehatan, 8(1), p. 41. doi: 10.31983/jrk.v8i1.3844.

Rofi'ah, S., Widatiningsih, S. and Sukini, T. (2019) 'Efektivitas Aromaterapi Lemon untuk Mengatasi Emesis Gravidarum', Jurnal Kebidanan, 9(1), pp. 9-16. doi: 10.31983/jkb.v9i1.3814.

Saifuddin, A. B. (2011) Ilmu Kebidanan. Jakarta: Yayasan Bina Pustaka Sarwono Prawirohardjo.

Setyaningsih, R. D., Adriyani, P. and Ulfah, M. (2016) 'Upaya Peningkatan Pengetahuan Ibu Hamil Dan Kader Posyandu Balita Tentang Pengenalan Tanda Bahaya Kehamilan Di Kabupaten Banyumas', Jurnal Pengabdian Kepada Masyarakat, 22(3), pp. 135-139.

Sulate, S. I. (2015) Hubungan Pengetahuan Tentang Emesis Gravidarum Terhadap Perilaku Ibu Hamil Pada Saat Mengalami Emesis Gravidarum Di Bpm Nihayatur Rohma Desa Kuningan Kecamatan Kanigoro Kabupaten Blitar Tahun 2015. Sekolah Tinggi Ilmu Kesehatan Patria Husada Blitar. Available at: https://books.google.co.id/books?id=Hr8 waKol42IC.

Suparmi dan Kusumadewi, R. R. (2018) ‘Pengaruh Sirup Jahe Merah Terhadap
Penurunan Hiperemesis Gravidarum Grade I Pada Ibu Hamil Di Plupuh Sragen', Viva Medika, 11(01), pp. 14-20.

Susanto, A. (2017) 'Peran Kader Posyandu sebagai Agen Perubahan Perilaku pada Ibu Hamil dalam Upaya Menekan Angka Kematian Ibu dan Bayi', in 2nd Seminar Nasional IPTEK Terapan (SENIT) 2017. Tegal: Politeknik Harapan Bersama Tegal, pp. 189-193. Available at: http://conference.poltektegal.ac.id/index. $\mathrm{php} /$ senit2017.

Widatiningsih, S., Rofiah, S. and Ristiyanawati (2018) 'The Use of Brewed Herbs Mouthwash for Overcoming Morning Sickness', in The 5th International Conference on Health Sciences (ICHS 2018). Yogyakarta: Atlantis Press. Available at: https://www.atlantis-press.com/ proceedi ngs/ichs-18/125921347.

Widiasari, N. P. A. and Trapika, I. G. M. S. C. (2017) 'Pola Pemberian Terapi Mual dan Muntah pada Ibu Hamil oleh Dokter Spesialis Obstetri dan Ginekologi serta Bidan di Kota Denpasar', E-Jurnal Medika, 6(5), pp. 28-35.

Wijhati, E. R., Suryantoro, P. and Rokhanawati, D. (2017) ‘Optimalisasi Peran Kader Dalam Pemanfaatan Buku Kia di Puskesmas Tegalrejo Kota Yogyakarta', Jurnal Kebidanan, 6(2), pp. 112-119. doi: 10.26714/jk.6.2.2017.112-119.

Wulandari, D. A., Kustriyanti, D. and Aisyah, R. (2019) 'Minuman Jahe Hangat untuk Mengurangi Emesis Gravidarum pada Ibu Hamil di Puskesmas Nalumsari Jepara', Jurnal SMART Kebidanan, 6(1), pp. 42-47. doi: 10.34310/sjkb.v6i1.246. 